\title{
NATURAL VENTILATION POTENTIAL OF THE MEDITERRANEAN COASTAL REGION OF CATALONIA
}

\author{
Nikola Pesic ${ }^{1}$, Jaime Roset Calzada ${ }^{2}$ and Adrian Muros Alcojor ${ }^{1}$ \\ Polytechnic University of Catalonia, Barcelona School of Architecture, Catalonia, Spain \\ ${ }^{1}$ Department of Architectural Technology \\ ${ }^{2}$ Department of Physics \\ e-mail address: nikola.pesic@upc.edu
}

\begin{abstract}
Most of the Catalonian population and urban areas are located along the Mediterranean coastal zone and for this analysis three largest Catalonia's cities are chosen: Barcelona, Terrassa and Tarragona. Each city is a geographical representative of a different climate type according to the re-analysed Köppen-Geiger climate classification. The objective of this research is to demonstrate the effects of regional climate variations on the potential of natural ventilation (NV) application in building design. The first part of the article presents the availability of NV corresponding to yearly climate conditions applying the methodology "Climate potential for natural ventilation" (CPNV). In the continuation, the second analysis is calculated with building energy simulation software and displays possible refrigeration energy savings in three geographical locations. Mixed-mode (or hybrid-mode) and night-ventilation techniques are applied for the cooling process of a hypothetical low-rise office building model.
\end{abstract}

Keywords: energy efficiency, energy transition, natural ventilation, passive cooling, mixed-mode, performance, Mediterranean region, Catalonia

\section{Introduction}

The Kingdom of Spain, as the member state of the European Union (EU), is currently in the so called "energy transition", that is to say, in the implementation process of renewable energy sources and energy efficiency in the domestic power system. The EU's outlined target for Spain's federal energy sector reform is to have $20 \%$ of renewable energies in the gross final energy consumption by the year 2020 , and $27 \%$ by 2030 as planned EU minimum, with a revision stage for the possible increase to $30 \%$. The current official level of implementation is $17.3 \%$ which is ahead of the projected $12.1 \%$ [1]. However, the positive image of "the progress made in achieving the objectives has basically been due to the development of renewable power generation and the economic crisis that has led to a reduction in energy consumption, but not to a structural change in final energy consumption" [2].

Catalonia, as an autonomous community of Spain, defined at its local level a preliminary energy efficiency program called "National pact for the Energy Transition of Catalonia" which is announced as a national priority project and defines the transition model during 2017-2050. The first phase for the year 2020 is determined the same as on Spain's federal level. Nevertheless, the 
intention for 2030 is to achieve $70 \%$ presence of renewable energies, and the final objective is a model named " $100 \%$ renewable in the year 2050 " for the domestic power system. According to the state policy, the ambition is to gain a higher "energetic independence" and to develop "an energy efficient and competitive country" [3].

Currently, non-renewable energy sources dominate in the Catalonia's energy production with $81.6 \%$, and the major part $53.5 \%$ is the nuclear power. The renewable energies participate with $18.4 \%$, where the primary sources are: hydropower $10.5 \%$, wind power $5.9 \%$, photovoltaic power $0.9 \%$ etc. [4]. Catalonia's building sector consumes $23.4 \%$ of the final electric energy, or $15.1 \%$ of the gross total final energy. Although Catalonia manages to lower down the average annual final electricity consumption by $0.3 \%$ [5], on the other side, at Spain's federal level the current average annual growth is $2.5 \%$ [6].

In this respect, the objective during the energy transition route is to search, investigate and implement renewable energy sources in all sectors with a regard to outweigh the current domination of non-renewable energies [3].

Since the concerns for the human environment and energy efficiency emerged on the world scale, the natural ventilative cooling strategies became one of the key components in the modern energyefficient building design. NV passive techniques are deeply rooted throughout the history and nowadays are updated according to new investigations in the fields of human hygrothermal comfort and sustainable building design.

This paper describes the geo-climatic applicability of NV in the Mediterranean coastal region of Catalonia, the autonomous community of the Kingdom of Spain, located in the northeast part of the Iberian Peninsula in the southwest corner of Europe continent. The scope of this research is to provide useful guidelines and basic energy efficiency parameters mainly to architects, engineers and policy makers in order to visualize the climate potential for the implementation of NV systems. NV strategies could be applied on a larger scale, along with other renewable energy techniques, with the final aim to make a more significant role in the present shifting towards the reduction of energy loads in the Catalonia's building sector.

Specific studies for the evaluation of NV potential that were recently conducted are also related to the Mediterranean climate system. The global analysis done by Chen et al. [7] calculated NV potential of 1854 geographic locations using "NV hour" parameter. Furthermore, the comparative energy savings for the world's 60 largest cities are calculated with a detailed building simulation. At the level of the Mediterranean basin, Chiesa and Grosso [8] formulated "Cooling Degree Hour" ( $\mathrm{CDH})$ and the analysis also includes a correlation between actual adaptive thermal comfort standards. The ventilative cooling state-of-the-art overview elaborated by Kolokotroni and Heiselberg [9] displays the latest NV technological opportunities in the building sector with a wide spectre of evaluation tools and methods.

\section{Climate description}

The updated Köppen-Geiger map of the world climate classification [10] and the recently published high-resolution map (representing data for the more recent 25-year period 1986-2010) [11], display a more detailed climate diversity of this part of Iberian Peninsula (Figure 1). Three climate types are prevailing along the seaside of Catalonia: "Csa" - Hot-summer Mediterranean climate, "Cfa" - Humid subtropical climate and "Bsk" - Cold semi-arid. "Csa" is the typical climate along the Mediterranean coast, while the areas influenced more by the continental climate are classified as "Bsk" climate type. On the other side, the lower part of the northern mountain range along the coastline is mainly categorized as type "Cfa". 


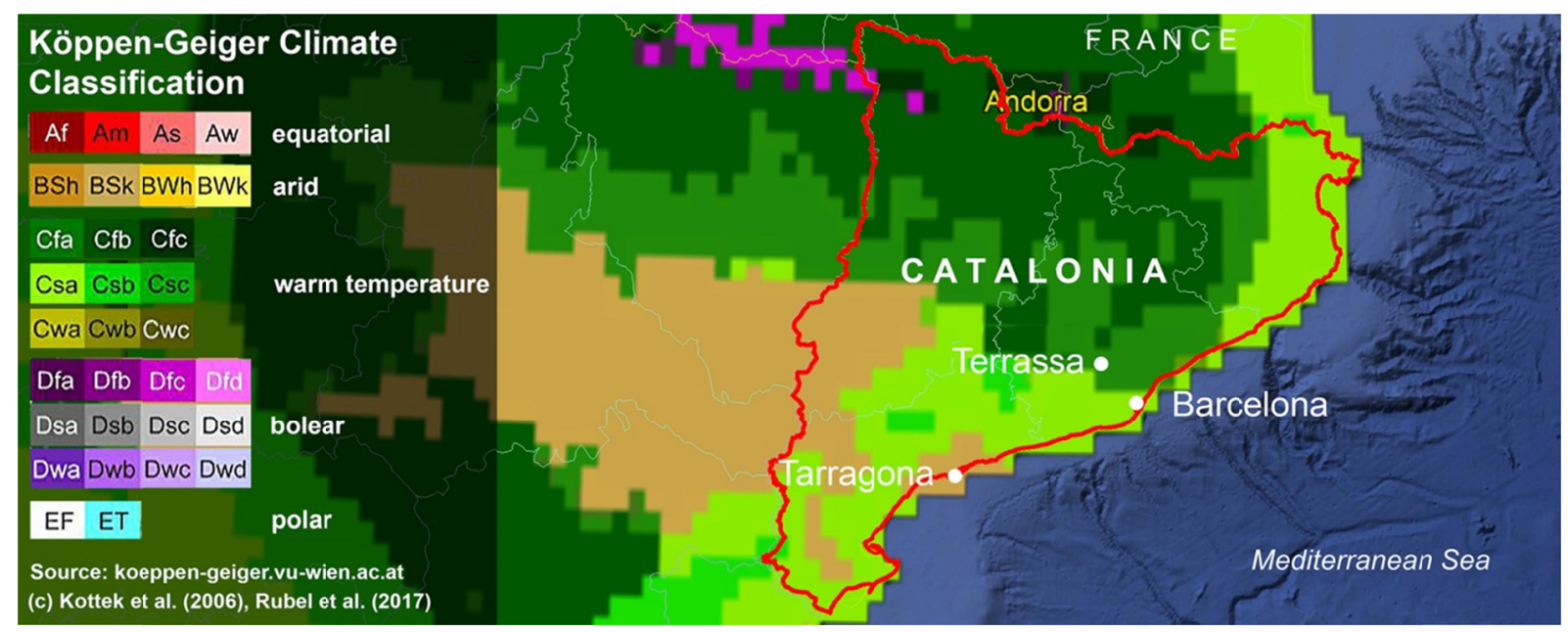

Figure 1. Geographical map of Catalonia with Köppen-Geiger Climate Classification [11] (high-resolution 5 arc minutes map and data file Global_1986-2010_KG_5m.kmz, generated by “Google Earth" software, edited image)

The majority of Catalonia's population and urban areas are concentrated along the coastal territory [12]. Three largest regional cities are chosen for this research: Barcelona, Terrassa and Tarragona, and each one is a geographic representative of a different climate type (Table 1).

\begin{tabular}{|c|c|c|c|c|c|c|c|c|c|c|c|c|c|c|}
\hline \multirow[b]{3}{*}{ city } & \multirow{3}{*}{$\begin{array}{l}\text { Climate } \\
\text { zone }\end{array}$} & \multirow{3}{*}{$\begin{array}{l}\text { MAMSL } \\
(\mathrm{m})\end{array}$} & \multicolumn{12}{|c|}{ Average annual climate data } \\
\hline & & & \multicolumn{3}{|c|}{ Dry bulb temperature $\left({ }^{\circ} \mathrm{C}\right)$} & \multirow{2}{*}{$\begin{array}{c}\text { Relative } \\
\text { humid. (\%) }\end{array}$} & \multicolumn{4}{|c|}{ Wind speed $(\mathrm{m} / \mathrm{s})$} & \multicolumn{4}{|c|}{ Wind direction $\left({ }^{\circ}\right)$} \\
\hline & & & Low & Average & High & & Spring & Summer & Autumn & Winter & Spring & Summer & Autumn & Winter \\
\hline Barcelona & Csa & 6 & 11.9 & 15.7 & 19.7 & 74 & 3.2 & 3.1 & 3.2 & 3.9 & 175 & 176 & 173 & 247 \\
\hline Terrassa & $\mathrm{Cfa}$ & 235 & 11.9 & 15.7 & 19.8 & 69 & 2.7 & 2.4 & 2.4 & 2.4 & 195 & 187 & 194 & 210 \\
\hline Tarragona & Bsk & 34 & 13.1 & 17.3 & 21.9 & 63 & 3.4 & 3 & 2.9 & 3.1 & 195 & 187 & 194 & 210 \\
\hline
\end{tabular}

Table 1. Catalonia's three cities: Climate zone, meters above sea level (MAMSL) and average annual climate data

Barcelona is the capital city and the largest port of Catalonia. It spreads on a coastal plateau encircled by the sea to the east, the mountain range to the west and two rivers to the south and to the north. The city of Terrassa is located $25 \mathrm{~km}$ to the north-west from Barcelona, on the altitude of $235 \mathrm{~m}$ above sea level (MAMSL) where dominates mountain forest terrain. Tarragona is the coastal city situated $100 \mathrm{~km}$ to the south-west from Barcelona and is the second largest Catalonia's port.

This region is exposed to the effects of global climate change and among registered climate anomalies is the yearly temperature increase by $0.24^{\circ} \mathrm{C}$ per decade, regarding the observation period 1950-2011 [13]. The most intense change is during the summer season with the increase up to $0.36{ }^{\circ} \mathrm{C}$ per decade. Taking as a reference data period 1971-2000 and projecting the variables for the period 2001-2050, the results are showing that the average yearly temperature could rise between $0.8^{\circ} \mathrm{C}$ and $1.8^{\circ} \mathrm{C}$ by the year 2050 [14].

\section{Methodology}

The methodology "Climate Potential of Natural Ventilation" (CPNV), developed by Causone [15], is applied in the first part of this analysis. The aim is to present a general valorisation of NV potential respecting local climate conditions. The objective is to calculate the total number of hours for the theoretical acceptable use of NV throughout a calendar year, for both ventilation and cooling effect, during day and night and regardless the wind force effect.

The second part of this article presents comparative calculations for the possible energy savings during a cooling period based on a performance simulation of a hypothetical office-building 
model. Five different cross-ventilation (or wind-driven ventilation) principles are applied which are operating during a defined yearly refrigeration period from April to October.

\subsection{Climate potential of natural ventilation (CPNV)}

CPNV methodology [15] is a preliminary design tool which provides an overview of climate conditions for a particular geographical location.

The CPNV coefficient is calculated as the total number of NV hours during a year period divided by the total number of 8760 hours in a calendar year $\left(h_{t o t}\right)(1)$, where $h_{N V, i}$ is "i"-th hour when NV could be performed.

$$
\mathrm{CPNV}=\frac{\sum_{i=1}^{n} h_{N V, i}}{h_{t o t}}
$$

Based on the average hourly meteorological database, two parameters are defined: the ambient temperature $\left(t_{\text {out }}\right)$ and the ambient humidity ratio $\left(W_{\text {out }}\right)$. The boundary conditions are set that the ambient temperature must be within the comfort range of the lower and upper acceptable indoor temperature $\left(t_{i n, l} ; t_{i n, u}\right)(2)$ and that the humidity ratio must be within the range of the indoor upper and lower acceptable humidity ratio $\left(W_{i n, l} ; W_{i n, u}\right)$ (3). Complying both these conditions, a naturally ventilated space can be hygrothermally accepted by the occupants (Figure 2).

$$
\begin{gathered}
t_{i n, l} \leq t_{\text {out }} \leq t_{\text {in,u }} \\
W_{\text {in,l }} \leq W_{\text {out }} \leq W_{\text {in }, u}
\end{gathered}
$$

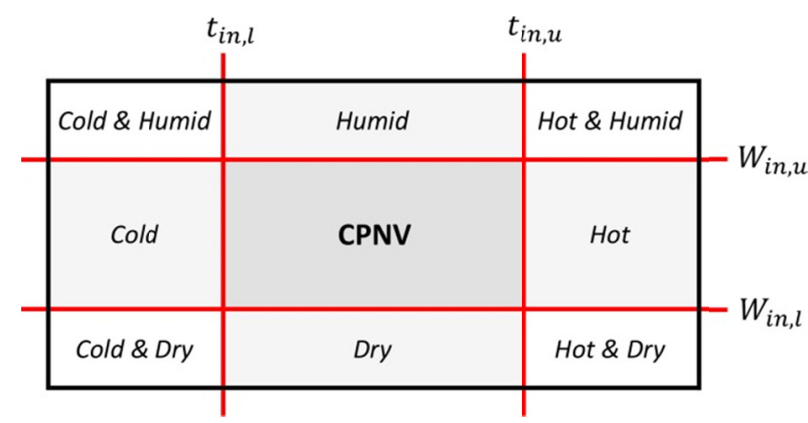

Figure 2. The boundary conditions: time of year subdivided in 9 areas according to temperature and humidity ratio thresholds (source: "Climate Potential of Natural Ventilation (CPNV)", Francesco Causone, 2016.)

In this case is applied a part of the ASHRAE Standard 55-2017 for the "adaptive model" of thermal comfort [16] that $80 \%$ of the occupants find the interior NV environment thermally accepted. In this respect, the indoor boundary conditions are defined as the lower and upper acceptable indoor air temperature limits $\left(t_{l} ; t_{u}\right)(4,5)$.

$t_{l}=t_{\text {comf }}-3.5^{\circ} \mathrm{C}$

$t_{u}=t_{\text {comf }}+3.5^{\circ} \mathrm{C}$

The temperature range limits are defined with the comfort ambient temperature $\left(t_{\text {comf }}\right)$, which is calculated with the prevailing mean outdoor air temperature $\left(t_{\text {pma(out })}\right)$ as a simple arithmetic mean of hourly outdoor air temperatures of seven sequential days prior to the day in question, according to ASHRAE 55-2017 standard. $t_{\text {comf }}$ is calculated with the following equation (6):

$$
t_{\text {comf }}=17.8+0.31 \times t_{\text {pma(out) }}
$$


The lower limit for the supply air temperature $\left(t_{i n, l}\right)$ is set at $10^{\circ} \mathrm{C}(7)$ and the upper limit $\left(t_{i n, u}\right)$ is set to be equal to the upper indoor acceptable temperature $\left(t_{u}\right)$, but less than $33.5^{\circ} \mathrm{C}$ as the maximum air supply temperature level (8).

$t_{i n, l}=10^{\circ} \mathrm{C}$

$t_{i n, u}=t_{u} ; t_{i n, u}<33.5^{\circ} \mathrm{C}$

The usually considered acceptable interior air $\mathrm{RH}$ level is between $30 \%$ and $70 \%$, as it is elaborated in CPNV methodology related to other common known sources. On the other side, according to CEN Standard EN15251, it is stated that "humidity has only a small effect on thermal sensation and perceived air quality in the rooms of sedentary occupancy" [17]. Another research suggests that "no specific guidance is provided for natural ventilation systems. If higher moisture levels are allowed, materials should be selected to be moisture tolerant" [18]. In addition, an article which analyses the NV function in hot-humid climates, affirmed that there is no required upper limit for the interior air RH [19].

This part of the Mediterranean basin is characterized with a higher outdoor air RH level, and the highest annual $\mathrm{RH}$ among three analysed cities is $74 \%$ in Barcelona. In this regard and particularly for this study, the upper $\mathrm{RH}$ limit $\left(R H_{u}\right)$ is adapted to the previously described local Mediterranean climate and is set to $80 \%$ while the lower relative humidity limit $\left(R H_{l}\right)$ is maintained at $30 \%$.

According to the CPNV methodology, both lower and upper humidity ratio limits $\left(W_{i n, l} ; W_{i n, u}\right)$ for the outdoor supply-air are calculated with the following equations $(9,10)$ where the saturation pressure of water vapour $\left(p_{w s}\right)$ is a function of the lower indoor air temperature limit $\left(t_{l}\right)$ :

$$
\begin{array}{ll}
W_{i n, l}=0.621945 \times \frac{p_{w s} \times 0.3}{p-\left(p_{w s} \times 0.3\right)} ; & p_{w s}=f\left(t_{l}\right) \\
W_{i n, u}=0.621945 \times \frac{p_{w s} \times 0.8}{p-\left(p_{w s} \times 0.8\right)} ; & p_{w s}=f\left(t_{l}\right)
\end{array}
$$

The considered equation for the approximate calculation of $p_{w s}$ is:

$p_{w s}=610.7 \times 10^{7.5 \times t_{l} /\left(237.3+t_{l}\right)}$

Regarding the NV operation time, a 24 hour day period is divided in two cycles: the presumed working time schedule $08-18 \mathrm{~h}$ and the rest of the day $19-07 \mathrm{~h}$, usually considered as the night-time ventilation period [20].

\subsection{Building energy simulation}

A model of an office type three-story open-plan building (Figure 10) is designed with DesignBuilder (DB) software [21] in order to calculate the possible energy savings for each of three cities within its climate zones. The software model represents a basic office narrow-plan building wing, with limits on the zone common height to depth ratios: the footprint dimensions are $15 \mathrm{~m} \times 50 \mathrm{~m}$ and the floor-to-floor height is $\mathrm{h}=3.5 \mathrm{~m}$. Gross floor area is $750 \mathrm{~m}^{2}$. The basic cross-ventilation passive technique is used, that is to say, the outdoor air is introduced through façade operable windows and the air movement is generated primary by the wind force. 


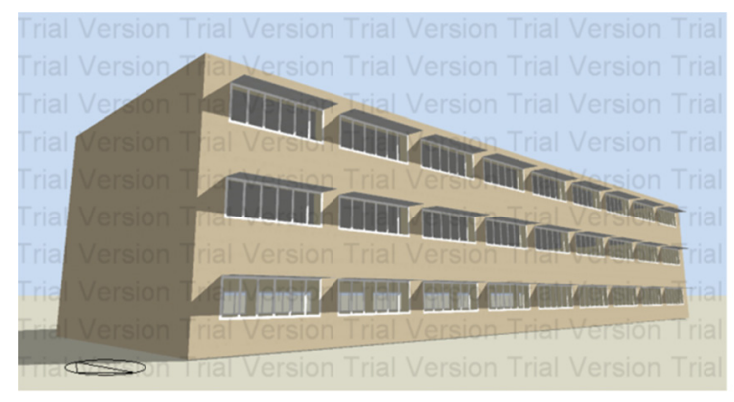

(a)
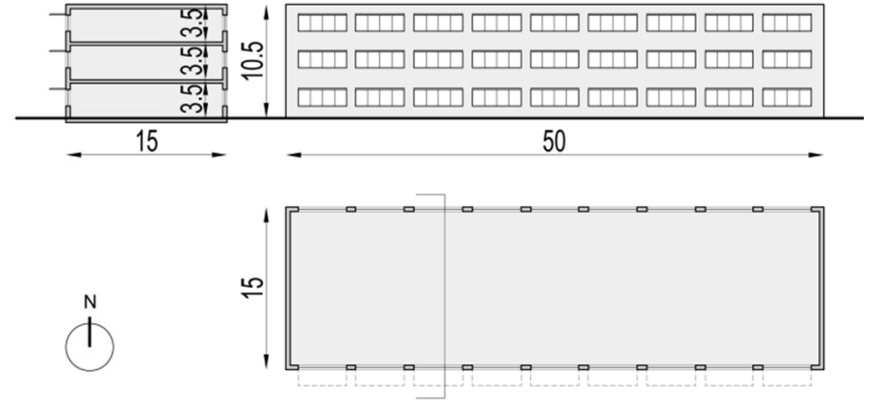

(b)

Figure 10. DesignBuilder simulation building model (a), building plan, section and south elevation (b)

\begin{tabular}{ll|ll|ll} 
Footprint dim: & $50 \mathrm{~m} \times 15 \mathrm{~m}$ & Heating temp. : & $21^{\circ} \mathrm{C}$ & Occupancy : & $08-18 \mathrm{~h}$ \\
\hline Floor-to-floor: & $3.5 \mathrm{~m}$ & Cooling temp. : & $23^{\circ} \mathrm{C}$ & HVAC system : & $06-18 \mathrm{~h}$ \\
\hline Gross area: & $750 \mathrm{~m}^{2}$ & Economizer : & Off & Daily NV : & $06-18 \mathrm{~h}$ \\
\hline MV fresh air: & $10 \mathrm{l} / \mathrm{s}$ per person & Humid./Dehumid. & Off & Night NV : & $21-06 \mathrm{~h}$
\end{tabular}

Table 2. General Designbuilder building model parameters

During the favourable months for NV function (April, May, and October) the wind directions in this region are mainly between $175^{\circ}$ and $195^{\circ}$. In that manner, the building axis is positioned perpendicularly to the wind directions, oriented west-east, in favour to maximize NV effect. Glazed surface, or window-to-wall ratio, is set at $40 \%$ and the building envelope infiltration is with a constant annual rate of $0.250 \mathrm{ac} / \mathrm{h}$.

The reference HVAC system is basic Variable Air Volume (VAV) type, commonly used in office buildings, as a relatively energy efficient air-conditioning system. Cooling system seasonal CoP value is set at 5 , the economizer operation mode is not activated and the constant mechanical ventilation (MV) is delivering minimum fresh air at $10 \mathrm{l} / \mathrm{s}$ per person during the occupation schedule.

The cooling and heating set point temperatures are $21^{\circ} \mathrm{C}$ and $23^{\circ} \mathrm{C}$, the outdoor supply air temperature lower and upper limits for $\mathrm{NV}$ operation are $10^{\circ} \mathrm{C}$ and $33.5^{\circ} \mathrm{C}$ and the $\mathrm{HVAC}$ interior space humidification/dehumidification is not activated. The occupancy schedule is 08:00-18:00h and the HVAC operation schedule is $06: 00-18: 00 \mathrm{~h}$ while the night-time ventilation is programmed 21:00-06:00h to flush out the accumulated heat during the day (Table 2). To avoid the possible space overcooling and thermal deviation effect provoked by night-time ventilation [22], the $2 \mathrm{~h}$ time period is set between the end of the night ventilation process and the start of the working time schedule. All schedules are set from Monday to Friday. The building materialization and insulation are defined according to "Passivhaus" standards and for the purpose of the comparative analysis of possible efficient energy use, $\mathrm{NV}$ is set to be equally operative for all three cities from 01st April to 31st October.

Six ventilation modes are programmed in order to compare possible energy savings during the defined refrigeration period from April to October:

1. Fully air-conditioned mode (FullAC)

The "sealed" building model: fully operated HVAC system with MV and without any $\mathrm{NV}$ operation. It is defined as a reference model for possible comparisons of cooling energy savings with other NV based modes.

2. Mixed-mode type: Change-over mode (COM)

"Same space, different times": the automated system is switching between HVAC system and NV function which is controlled by the automatically controlled operable windows. Both systems are covering the same space but operating in different times. 
Facade windows are automatically opened to provide NV when the HVAC system is in economizer mode, and then closed when the system is in cooling mode [23].

3. Mixed-mode type: Change-over daily mode and night-time ventilation $(\mathrm{COM}+\mathrm{NtV})$

4. Mixed-mode type: Concurrent mode (CM)

"Same space, same time": NV and HVAC system are operating in the same space and in the same time. NV is controlled by the manually operated windows and HVAC system may serve as supplemental or "background" ventilation and cooling while occupants are free to open windows based on individual preference. Perimeter VAV zones of the open-plan space may go to minimum air when sensor indicates that a window has been opened [23].

5. Mixed-mode type: Concurrent daily mode and night-time ventilation $(\mathrm{CM}+\mathrm{NtV})$

6. Night-time ventilation (NtV)

"Night-purge", as a passive cooling technique is set 21:00-06:00h, without any interaction with the daily FullAC operation 06:00-18:00h.

As a part of software calculations, it is applied the ASHRAE Standard-5; for the "adaptive model" of thermal comfort that $80 \%$ of the occupants find the interior environment thermally acceptable which is also the limit for the maximum capacity of possible refrigeration energy savings.

\section{Results}

\subsection{Climate potential of natural ventilation (CPNV)}

The following tables (Figures 3-5) display the calculated monthly boundary conditions with CPNV yearly value for the cities of Barcelona, Terrassa and Tarragona. The parallel charts show percentage of time when NV is pursuable during two defined daily cycles.

\begin{tabular}{|c|c|c|c|c|c|c|c|c|c|}
\hline \multirow[t]{3}{*}{ Barcelona } & \multicolumn{4}{|c|}{ Indoor boundary conditions } & \multicolumn{4}{|c|}{ Supply air acceptable conditions } & \multirow{3}{*}{ CPNV } \\
\hline & $t_{l}$ & $t_{u}$ & $R H_{l}$ & $R H_{u}$ & $t_{i n, l}$ & $t_{i n, u}$ & $W_{i n, l}$ & $W_{i n, u}$ & \\
\hline & ${ }^{\circ} \mathrm{C}$ & ${ }^{\circ} \mathrm{C}$ & $\%$ & $\%$ & ${ }^{\circ} \mathrm{C}$ & ${ }^{\circ} \mathrm{C}$ & $\mathrm{g} / \mathrm{kg}$ & $\mathrm{g} / \mathrm{kg}$ & \\
\hline January & 16.8 & 23.8 & 30 & 80 & 10.0 & 23.8 & 3.55 & 9.56 & \multirow{12}{*}{0.60} \\
\hline February & 17.2 & 24.2 & 30 & 80 & 10.0 & 24.2 & 3.64 & 9.79 & \\
\hline March & 17.7 & 24.7 & 30 & 80 & 10.0 & 24.7 & 3.76 & 10.13 & \\
\hline April & 18.4 & 25.4 & 30 & 80 & 10.0 & 25.4 & 3.91 & 10.54 & \\
\hline May & 19.6 & 26.6 & 30 & 80 & 10.0 & 26.6 & 4.22 & 11.38 & \\
\hline June & 20.8 & 27.8 & 30 & 80 & 10.0 & 27.8 & 4.55 & 12.28 & \\
\hline July & 21.6 & 28.6 & 30 & 80 & 10.0 & 28.6 & 4.78 & 12.92 & \\
\hline August & 21.8 & 28.8 & 30 & 80 & 10.0 & 28.8 & 4.84 & 13.07 & \\
\hline September & 21.0 & 28.0 & 30 & 80 & 10.0 & 28.0 & 4.61 & 12.45 & \\
\hline October & 19.7 & 26.7 & 30 & 80 & 10.0 & 26.7 & 4.24 & 11.45 & \\
\hline November & 18.1 & 25.1 & 30 & 80 & 10.0 & 25.1 & 3.84 & 10.33 & \\
\hline December & 17.4 & 24.4 & 30 & 80 & 10.0 & 24.4 & 3.67 & 9.89 & \\
\hline
\end{tabular}

a)

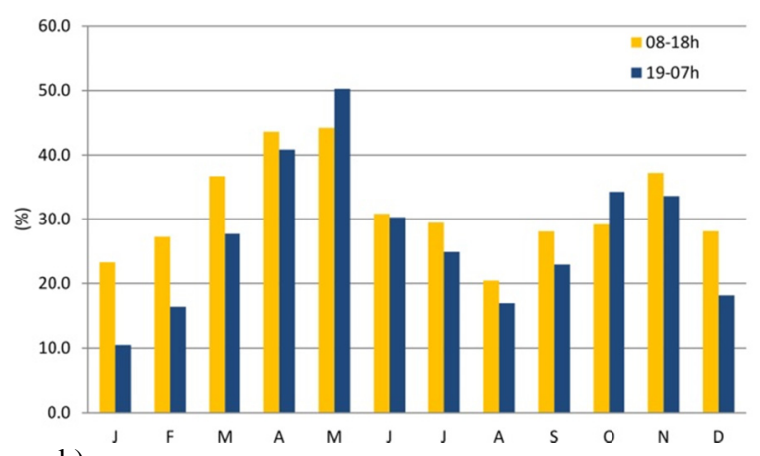

b)

Figure 3. Barcelona - yearly boundary conditions (a) and monthly distribution of NV, periods: 08-1 8h and 19-07h (b) 


\begin{tabular}{|c|c|c|c|c|c|c|c|c|c|}
\hline \multirow[t]{3}{*}{ Terrassa } & \multicolumn{4}{|c|}{ Indoor boundary concitions } & \multicolumn{4}{|c|}{ Supply air acceptable conditions } & \multirow{3}{*}{ CPNV } \\
\hline & $t_{l}$ & $t_{u}$ & $R H_{i}$ & $\mathrm{RH}_{u}$ & $t_{i n, l}$ & $t_{i n, u}$ & $W_{i n, l}$ & $W_{i n, u}$ & \\
\hline & ${ }^{\circ} \mathrm{C}$ & ${ }^{\circ} \mathrm{C}$ & $\%$ & $\%$ & ${ }^{\circ} \mathrm{C}$ & ${ }^{\circ} \mathrm{C}$ & $\mathrm{g} / \mathrm{kg}$ & $\mathrm{g} / \mathrm{kg}$ & \\
\hline January & 16.7 & 23.7 & 30 & 80 & 10.0 & 23.7 & 3.53 & 9.49 & \multirow{12}{*}{0.71} \\
\hline February & 17.1 & 24.1 & 30 & 80 & 10.0 & 24.1 & 3.61 & 9.71 & \\
\hline March & 17.9 & 24.9 & 30 & 80 & 10.0 & 24.9 & 3.81 & 10.26 & \\
\hline April & 18.6 & 25.6 & 30 & 80 & 10.0 & 25.6 & 3.97 & 10.70 & \\
\hline May & 19.8 & 26.8 & 30 & 80 & 10.0 & 26.8 & 4.29 & 11.57 & \\
\hline June & 21.1 & 28.1 & 30 & 80 & 10.0 & 28.1 & 4.65 & 12.55 & \\
\hline July & 21.8 & 28.8 & 30 & 80 & 10.0 & 28.8 & 4.85 & 13.11 & \\
\hline August & 21.8 & 28.8 & 30 & 80 & 10.0 & 28.8 & 4.86 & 13.13 & \\
\hline September & 20.7 & 27.7 & 30 & 80 & 10.0 & 27.7 & 4.52 & 12.19 & \\
\hline October & 19.7 & 26.7 & 30 & 80 & 10.0 & 26.7 & 4.25 & 11.45 & \\
\hline November & 17.9 & 24.9 & 30 & 80 & 10.0 & 24.9 & 3.81 & 10.26 & \\
\hline December & 16.9 & 23.9 & 30 & 80 & 10.0 & 23.9 & 3.56 & 9.59 & \\
\hline
\end{tabular}

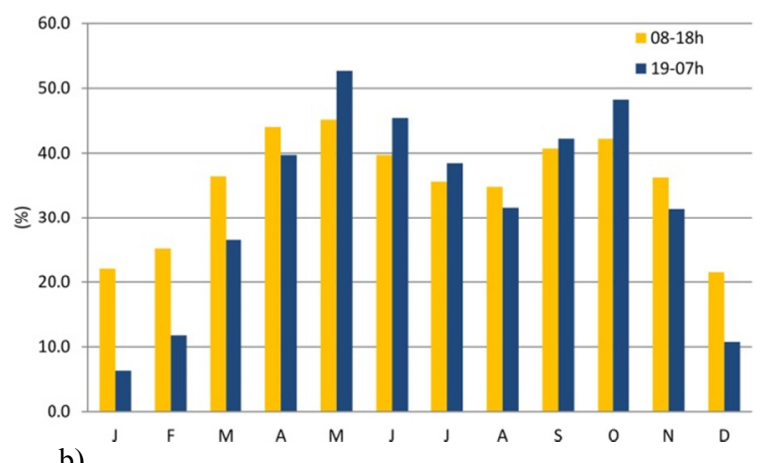

a)

b)

Figure 4. Terrassa - yearly boundary conditions (a) and monthly distribution of NV, periods: $08-18 \mathbf{h}$ and $19-07 \mathrm{~h}$ (b)

\begin{tabular}{|c|c|c|c|c|c|c|c|c|c|}
\hline \multirow[t]{3}{*}{ Tarragona } & \multicolumn{4}{|c|}{ Indoor boundary conditions } & \multicolumn{4}{|c|}{ Supply air acceptable conditions } & \multirow{3}{*}{ CPNV } \\
\hline & $t_{l}$ & $t_{u}$ & $R H_{l}$ & $\overline{R H_{u}}$ & $t_{i n, l}$ & $t_{i n, u}$ & $W_{i n, l}$ & $W_{i n, u}$ & \\
\hline & ${ }^{\circ} \mathrm{C}$ & ${ }^{\circ} \mathrm{C}$ & $\%$ & $\%$ & ${ }^{\circ} \mathrm{C}$ & ${ }^{\circ} \mathrm{C}$ & $\mathrm{g} / \mathrm{kg}$ & $\mathrm{g} / \mathrm{kg}$ & \\
\hline January & 17.3 & 24.3 & 30 & 80 & 10.0 & 24.3 & 3.65 & 9.84 & \multirow{12}{*}{0.77} \\
\hline February & 17.7 & 24.7 & 30 & 80 & 10.0 & 24.7 & 3.74 & 10.08 & \\
\hline March & 18.5 & 25.5 & 30 & 80 & 10.0 & 25.5 & 3.93 & 10.60 & \\
\hline April & 19.1 & 26.1 & 30 & 80 & 10.0 & 26.1 & 4.09 & 11.02 & \\
\hline May & 20.3 & 27.3 & 30 & 80 & 10.0 & 27.3 & 4.41 & 11.89 & \\
\hline June & 21.6 & 28.6 & 30 & 80 & 10.0 & 28.6 & 4.78 & 12.91 & \\
\hline July & 22.3 & 29.3 & 30 & 80 & 10.0 & 29.3 & 4.99 & 13.50 & \\
\hline August & 22.3 & 29.3 & 30 & 80 & 10.0 & 29.3 & 5.00 & 13.52 & \\
\hline September & 21.2 & 28.2 & 30 & 80 & 10.0 & 28.2 & 4.67 & 12.60 & \\
\hline October & 20.1 & 27.1 & 30 & 80 & 10.0 & 27.1 & 4.37 & 11.78 & \\
\hline November & 18.4 & 25.4 & 30 & 80 & 10.0 & 25.4 & 3.92 & 10.55 & \\
\hline December & 17.4 & 24.4 & 30 & 80 & 10.0 & 24.4 & 3.68 & 9.91 & \\
\hline
\end{tabular}

a)

Figure 5. Tarragona - yearly boundary conditions (a) and monthly distributic

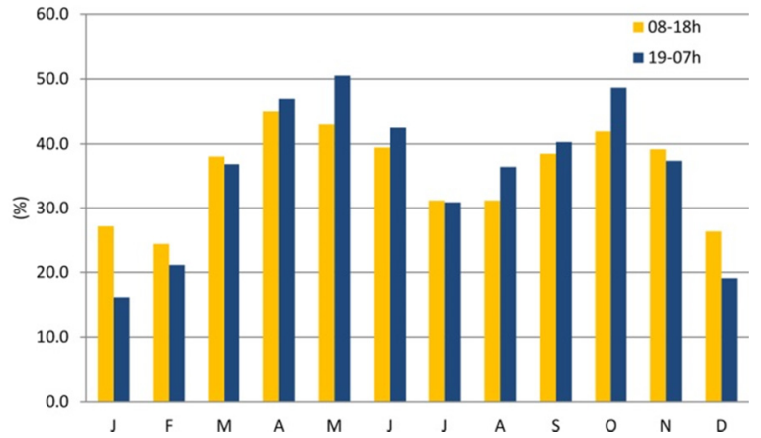

b)

The following charts (Figure 6) present the comparison of results for both regimes of NV (08-18h and 19-07h) for all three cities:

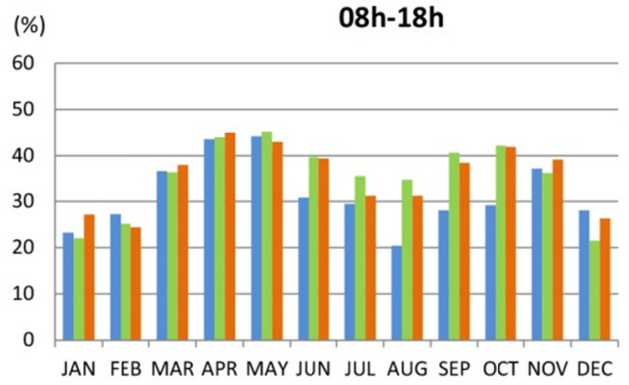

a)
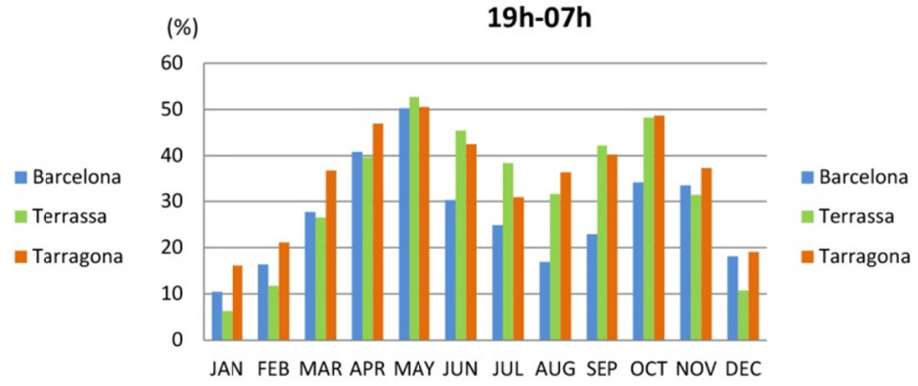

b)

Figure 6. Comparative monthly NV efficiency for the periods of use: 08-18h (a) and 19-07h (b)

The previously defined areas according to temperature and humidity ratio thresholds (Figure 2) can be generated with "heat maps" as a graphical representation of calculated values (Figures 79). Each "heat-map" demonstrates the general availability of NV throughout weekly/monthly weather conditions for each city location. 


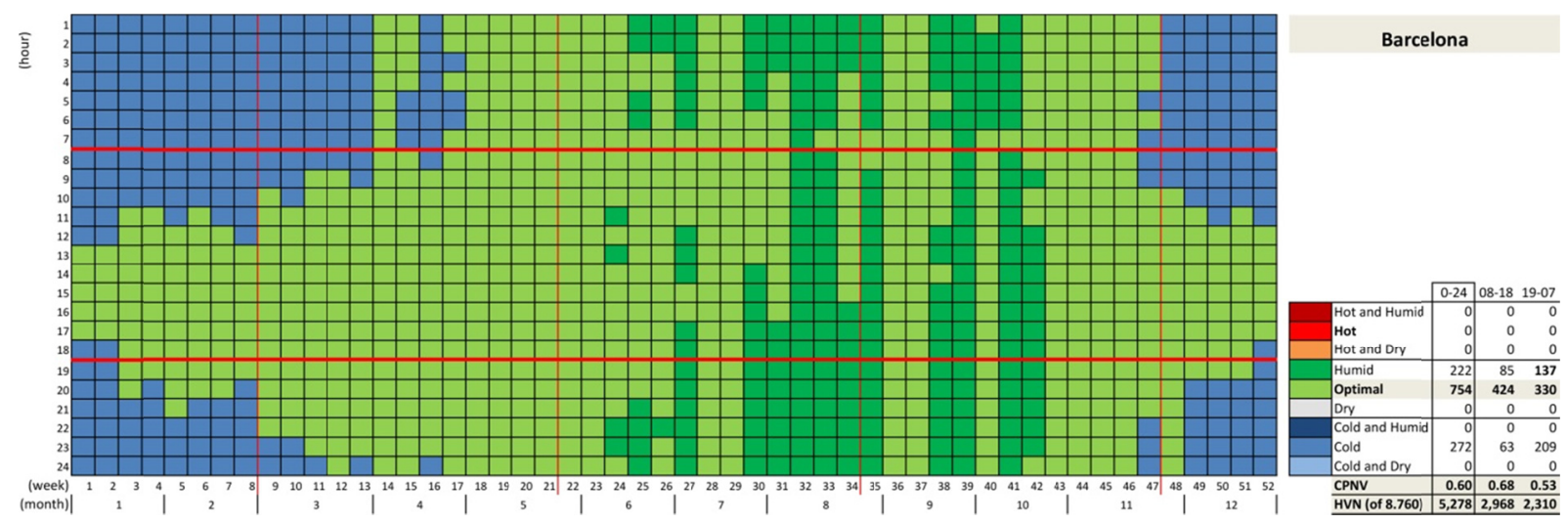

Figure 7. Barcelona - heat map (x-axis: weeks/months; y-axis: hours) and CPNV table overview

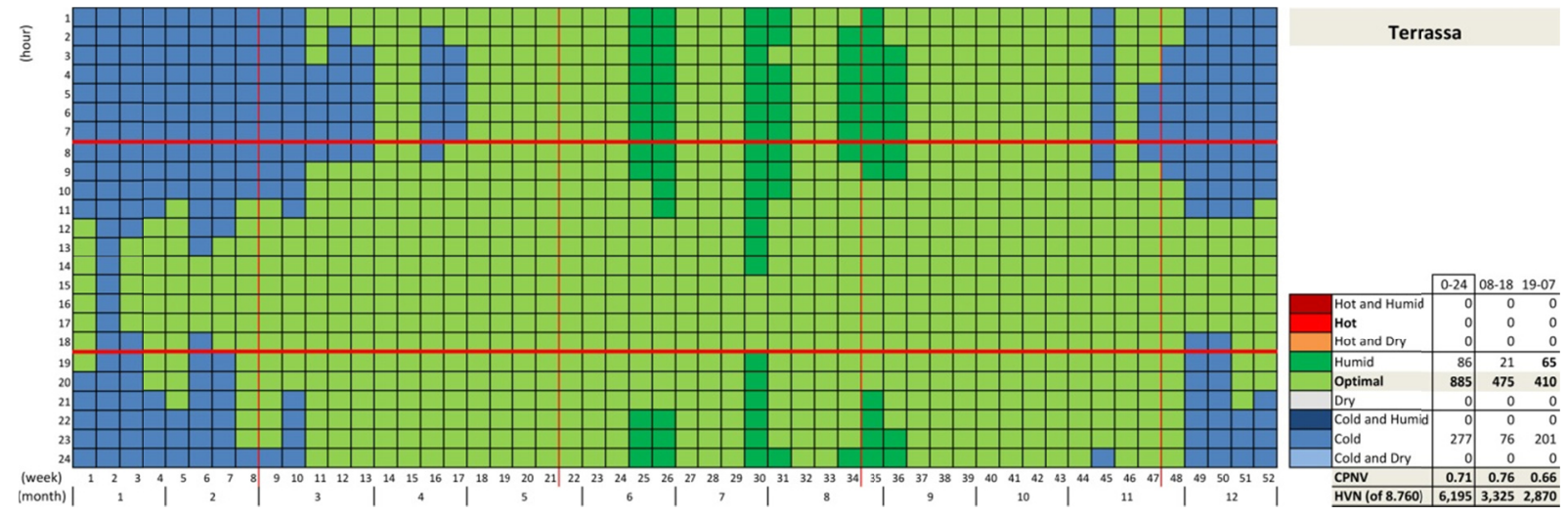

Figure 8. Terrassa: heat map (x-axis: weeks/months; y-axis: hours) and CPNV table overview

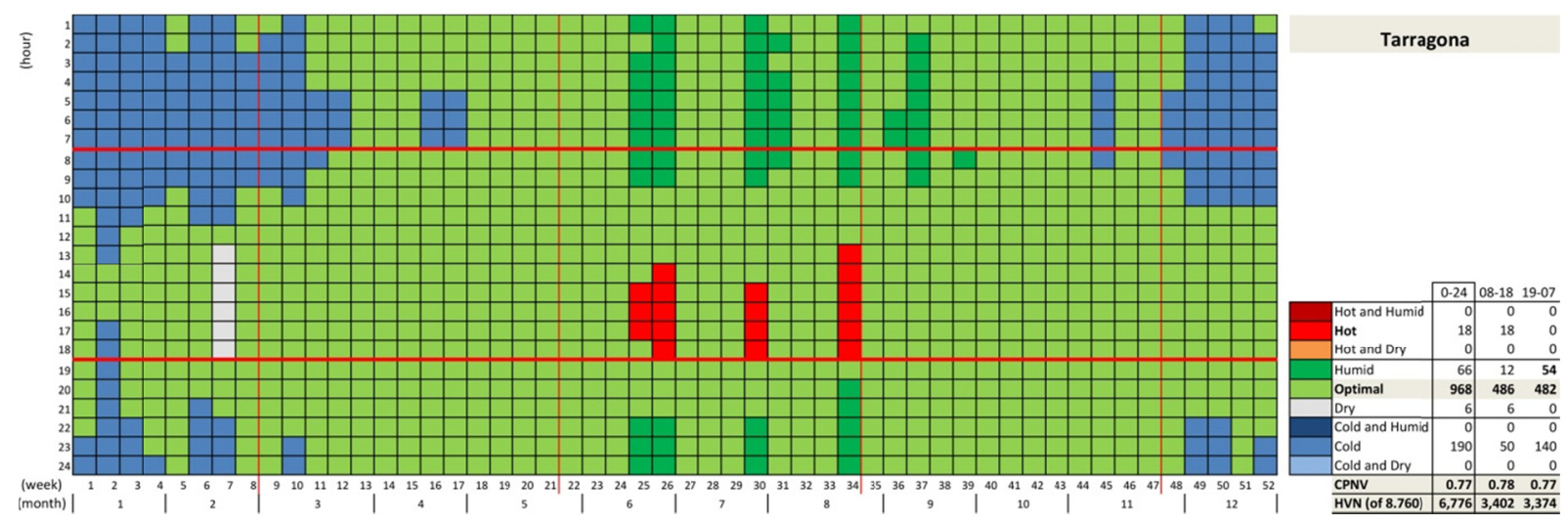

Figure 9. Tarragona: heat map (x-axis: weeks/months; y-axis: hours) and CPNV table overview

In Barcelona area, the favourable period for generating daily use of NV is during months of April and May (Figure 7), while in Terrassa and Tarragona is during April, May, September and October (Figures 8-9). The weather conditions during the late spring and throughout the summer (in the northern hemisphere), namely from June to August, demonstrate the particular differences between three climate zones. This is the period when CPNV is reduced as a result of unfavourable weather conditions in each observed geographical location. In that sense, Barcelona is characterized with periods of higher $\mathrm{RH}$, during both day and night. Terrassa has the mildest climate among three cities mainly as a result of lower mountain temperatures and a shorter summer period of elevated RH principally during the morning time. The location of Tarragona has generally a dryer climate with short periods of elevated outdoor temperatures in the late evening and high RH level during morning and night time. Regarding Tarragona overall higher annual outdoor air temperatures, CPNV is not significantly reduced because $\mathrm{NV}$ is more available 
during day-time period throughout all seasons, comparing to Barcelona and Terrassa locations results for the same period.

Ultimately, although the coastal location of Tarragona is certainly influenced with continental climate, in this case is classified as "Bsk" - Cold semi-arid climate zone. However, the generated output and the current weather data are indicating that the climate classification of the narrow Tarragona's coastal area (Figure 1) should probably be revised.

In general, the presented CPNV results show the accessibility to NV strategy without the consideration of wind effects. The results cover the yearly period for the theoretical NV use for both ventilation and refrigeration process in each geographical location. It can be considered that $\mathrm{NV}$ is mainly applicable from April to October, while the rest of the year, from November to March, NV can be used for the occasional interior space ventilation depending on the weather conditions.

\subsection{Cooling energy savings}

The following outputs (Table 3) present: the building models monthly reference FullAC mode energy consumption $\left(\mathrm{Wh} / \mathrm{m}^{2}\right)$, monthly cooling energy savings (\%) during April-October period, total yearly cooling energy demands $\left(\mathrm{kWh} / \mathrm{m}^{2}\right)$ and total yearly cooling energy savings $(\%)$.

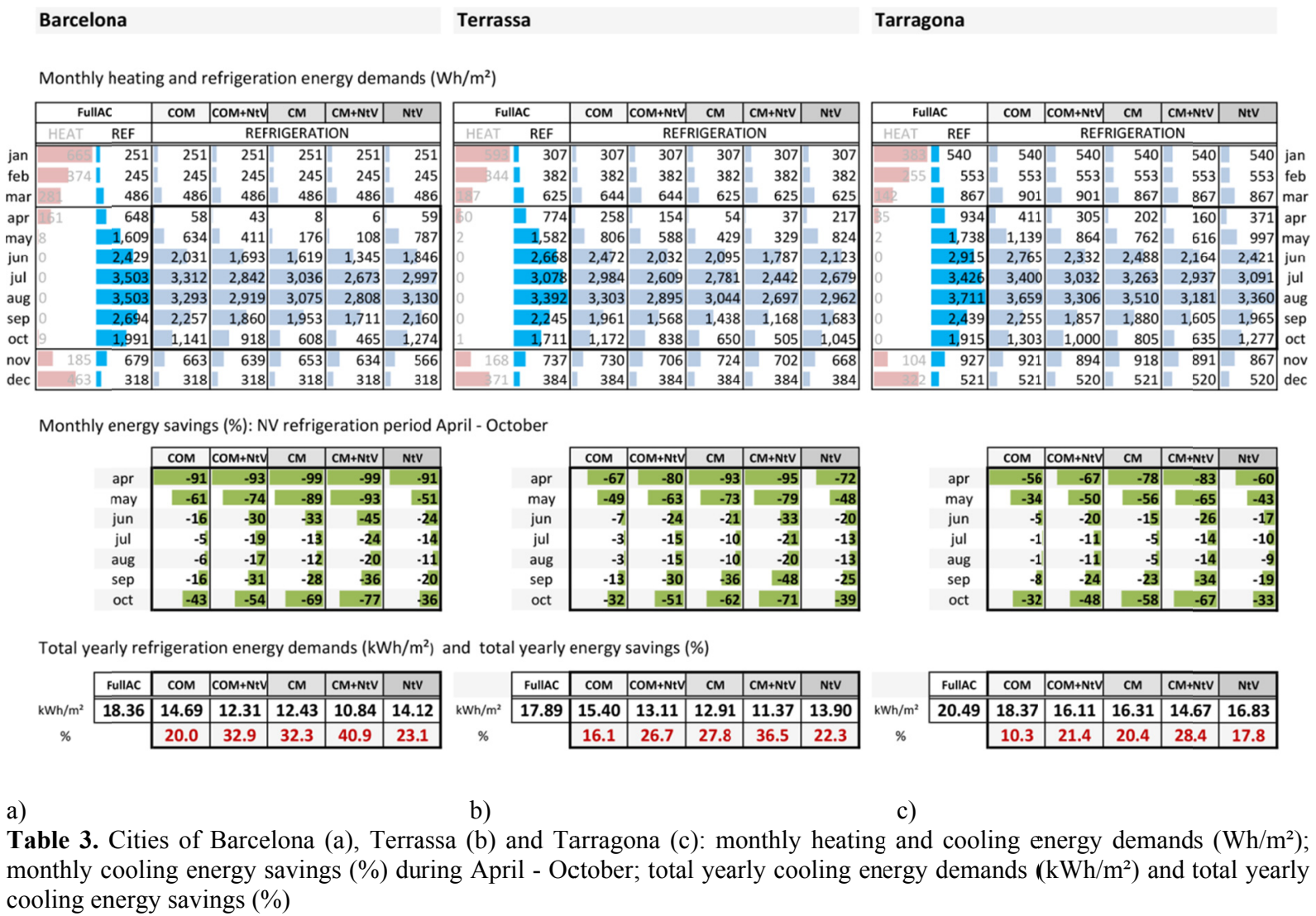

The comparative charts for the total annual refrigeration energy savings (Figure 11) correspondingly to five previously described NV modes (Section 3.2): 


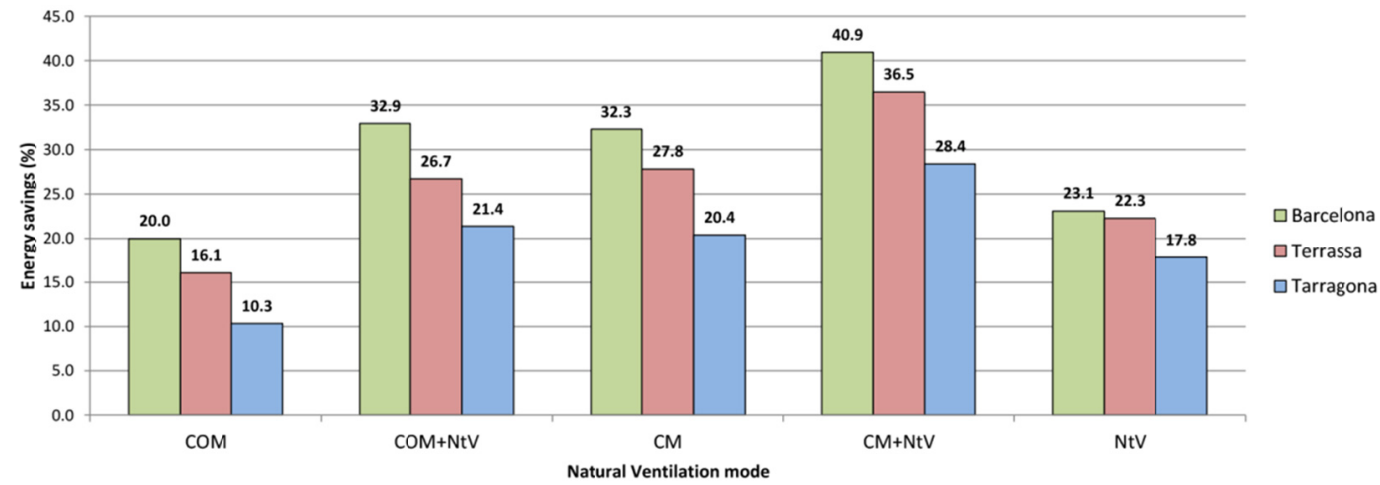

Figure 11: Comparative charts of annual energy savings (\%) for each $\mathrm{NV}$ mode $(\mathrm{COM}, \mathrm{COM}+\mathrm{NtV}, \mathrm{CM}, \mathrm{CM}+\mathrm{NtV}, \mathrm{NtV})$ for cities: Barcelona, Terrassa and Tarragona

As it is previously defined in CPNV analysis (Section 3.1), the proposed boundary levels for the interior air RH level are 30\% and 80\%. The bellow presented DB model outputs (Figure 12) are calculated during $\mathrm{CM}+\mathrm{NtV}$ operation when the interior space has the highest rate of exterior air infiltration produced both by NV (day and night operation) and daily use of MV. In all three cases the interior space RH levels, from 01 st April to 31 st October, are mainly within the $30 \%$ and $75 \%$ bands.

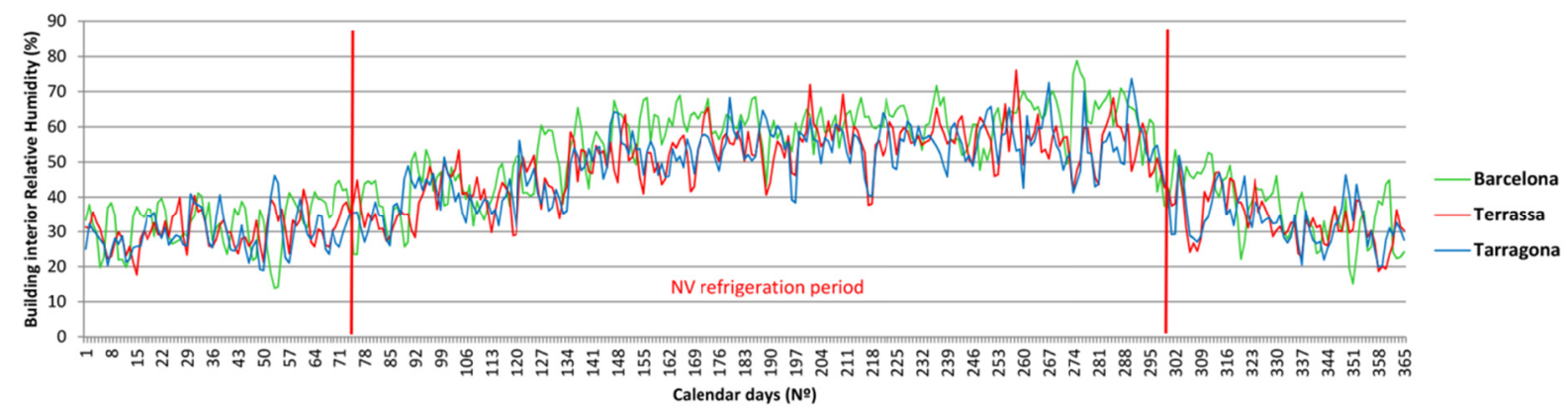

Figure 12: Interior level of air RH during a calendar year with $\mathrm{CM}+\mathrm{NtV}$ operation: Barcelona, Terrassa, Tarragona

Barcelona building model shows the highest level of energy savings as a result of more suitable climate conditions equally during day and night-time NV operation with respect also to the higher average wind speed. The results for the city of Tarragona demonstrate the lowest capacities of energy efficiency considering that the yearly outdoor temperatures are elevated and the corresponding energy demands for the refrigeration period are the highest among three building models.

In all three observed cases, the most efficient technique is the mixed-mode: concurrent mode with night-time ventilation $(\mathrm{CM}+\mathrm{NtV})$ where the building thermal comfort during $\mathrm{CM}$ operation is controlled by occupants with manually operable windows. The outcome of the best-case scenario for users-controlled windows, where the energy efficiency can be achieved between $28 \%$ and $48 \%$ (Figure 11), in the reality largely depends on the occupants' behaviour related to their individual and group thermal comfort response [24]. "A balance between user comfort and energy efficiency is required, as either extreme poses difficulties for the other" [25]. As the occupants prefer more control over their environment [26], after all, the automatic supportive control is recommended for achieving the designed comfort and to take over the system operation during non-occupied hours [27] (in this case mainly during the night-time mode and extreme weather conditions, both during day and night). Furthermore, the proper function of such ventilation system requires a communication with the occupants and their active participation in order to maintain the designed level of operating conditions [28]. 
Nonetheless, a moderate level of energy efficiency displays the simulation of night-time ventilation mode $(\mathrm{NtV})$, in the range between $18 \%$ and $23 \%$ (Figure 11), which is less technically demand and one passive energy saving technique. Barcelona location demonstrates a proportionally decreased $\mathrm{NtV}$ efficiency comparing to Terrassa and Tarragona as a result of lower temperature oscillations between day and night outdoor temperatures.

\section{Conclusions}

The first analysis, based on CPNV methodology, provides a visualisation of NV availability for each city geo-location regarding the human hygrothermal comfort and particular climate conditions taking into consideration both NV refrigeration and ventilation use throughout the year.

On the other side, in the second part of this research, the energy simulation outcome shows that $\mathrm{NV}$ is capable of reducing the building energy loads during the cooling period from April to October, with the different potential according to local climate conditions. In this context, certain weaknesses and strengths are indicated. The unfavourable weather conditions for day-time mixedmodes operations are during July and August, due to elevated outdoor temperatures, where the use of COM demonstrates the lowest energy saving capacity in the range between $1 \%$ and $6 \%$ (Table 3 ). However, the potential of day-time modes is most advantageous during transition seasons (spring and autumn), and moreover, in the combination with night-time ventilation such NV configurations can provide the calculated efficiency level throughout all yearly cooling period.

The final results display the opportunities regarding which part daily hybrid and night-ventilation modes can cover in the building cooling energy reduction. Here evaluated NV strategies could take a promising part in the overall reduction of building energy consumption along with the other contemporary sustainable techniques.

Despite the existing limitations, this paper is related to the theoretical use of NV based on the present meteorological database and the hygrothermal comfort conditions are partly adapted to the particular local climate system.

Respecting the meteorological data, future studies for this climate region should include actual scenarios of global climate change tendencies. The estimated temperature rise will surely produce the negative effects on the overall NV potential, notably during July and August where the particular day-time NV modes could be negligible. Regarding also that the global warming affects the timing of the seasons, the current typical building refrigeration period will tend to start earlier in spring and end later in autumn [9].

Moreover, future studies could also consider the adaptability of buildings to Mediterranean climate conditions through a defined structural type system that is capable to efficiently generate wind and/or buoyancy-driven NV principles. 


\section{References:}

[1] Ministerio de Industria, Energía y Turismo (MINETUR), «Nota de prensa. España, muy por encima de la senda prevista para lograr el objetivo del 20\% de renovables en 2020,» Ministerio de Industria, Energía y Turismo (MINETUR), Madrid, 2016.

[2] Deloitte Monitor, "A sustainable energy model for Spain in 2050. Policy recommendations for the energy transition," Deloitte, S.L. - Communications, Brand and Business Development department, Madrid, 2016.

[3] Institut Català d'Energia (ICAEN), «Bases per a constituir el Pacte Nacional per a la transició energètica de Catalunya,» Generalitat de Catalunya. Institut Català d'Energia (ICAEN), Barcelona, 2017.

[4] Institut Català d'Energia (ICAEN), «Potència elèctrica bruta instal·lada a Catalunya,» Generalitat de Catalunya. Institut Català d'Energia (ICAEN), Barcelona, 2016.

[5] Institut Català d'Energia (ICAEN), «Balance energético de Catalunya 1990-2014,» Generalitat de Catalunya. Institut Català d'Energia (ICAEN), Barcelona, 2016.

[6] European Environment Agency (EEA), "Indicator Assessment. Data and maps. Overview of electricity production and use in Europe. Average annual percentage change in final electricity consumption," European Environment Agency (EEA), Copenhagen, Published 15 Dec 2016. Last modified 13 Nov 2017. Accessed 15 Mar 2018. https://www.eea.europa.eu/data-andmaps/indicators/overview-of-the-electricity-production-2/assessment.

[7] Yujiao Chen, Zheming Tong, Ali Malkawi, "Investigating natural ventilation potentials across the globe: Regional and climatic variations," Building and Environment, no. 122, pp. 386-396, 2017.

[8] Giacomo Chiesa, Mario Grosso, "Geo-climatic applicability of natural ventilative cooling in the Mediterranean area," Energy and Buildings, no. 107, pp. 376-391, 2015.

[9] Maria Kolokotroni, Per Heiselberg, "Ventilative Cooling. State-of-The-Art Review. IEA - EBC Programme - Annex 62 Ventilative Cooling," Department of Civil Engineering. Aalborg University, Aalborg, 2015.

[10] Markus Kottek, Jürgen Grieser, Christoph Beck, Bruno Rudolf, Franz Rubel, "World Map of the Köppen-Geiger climate classification updated," Meteorologische Zeitschrift, vol. 15, no. 3, pp. 259-263, 2006.

[11] Kottek at al.(2006), Rubbel at al.(2017), "World Map of the Köppen-Geiger climate classification updated. High resolution map and data (version March 2017). KMZ file for Google Earth (high res): Global_1986-2010_KG_5m.kmz," Climate Change \& Infectious Diseases. http://koeppengeiger.vu-wien.ac.at, Wien, Published Mar 2017. Accessed 15 Mar 2018.

[12] Instituto de Estadística de Cataluña (IDESCAT), «Cifras de población: 2016,» Instituto de 
Estadística de Cataluña (IDESCAT), Barcelona, 2016.

[13] Equip de Canvi Climàtic - Àrea de Climatologia - Servei Meteorològic de Catalunya (METEOCAT), «Butlletí Anual d’Indicadors Climàtics. Any 2016,» Servei Meteorològic de Catalunya (METEOCAT). Generalitat de Catalunya, Departament de Territori i Sostenibilitat, Barcelona, 2017.

[14] Oficina Catalana del Canvi Climàtic (OCCC), «Estrategia Catalana de Adaptación al Cambio Climático (ESCACC). Resumen ejecutivo. Horizonte 2013-2020,» Generalitat de Catalunya, Departament de Territori i Sostenibilitat, Secretaria de Medi Ambienti i Sostenibilitat. Oficina Catalana del Canvi Climàtic (OCCC), Barcelona, 2012.

[15] Francesco Causone, "Climatic Potential for Natural Ventilation (CPNV)," Architectural Science Review, vol. 59, no. 3, pp. 212-228, 2016.

[16] American Society of Heating, Refrigerating and Air-Conditioning Engineers (ASHRAE), ANSI/ASHRAE Standard 55-2017. Thermal Environmental Conditions for Human Occupancy, Atlanta: American Society of Heating, Refrigerating and Air-Conditioning Engineers (ASHRAE), 2017.

[17] Comité Européen de Normalisation (CEN), "CEN Standard EN15251: Indoor environmental input parameters for design and assessment of energy performance of buildings - addressing indoor air quality, thermal environment, lighting and acoustics," Comité Européen de Normalisation (CEN), Brussels, 2007.

[18] Steven J. Emmerich, Brian Polidoro, James W. Axley, "Impact of adaptive thermal comfort on climatic suitability of natural ventilation," Energy and Buildings, vol. 43, p. 2101-2107, 2011.

[19] Doris Hooi Chyee Toe, Tetsu Kubota, "Development of an adaptive thermal comfort equation for naturally ventilated buildings in hot-humid climates using ASHRAE RP-884 database," Frontiers of Architectural Research, no. 2, p. 278-291, 2013.

[20] Nikolai Artmann, Heinrich Manz, Per Heiselberg, "Potential for passive cooling of buildings by night-time ventilation in present and future climates in Europe," Applied Energy, no. 84, p. $187-$ 201, 2007.

[21] DesignBuilder Software Ltd, «DesignBuilder v5.2,» DesignBuilder Software Ltd. https://www.designbuilder.co.uk, Stroud, Gloucestershire, Published 07 Sep 2016. Accessed 15 Mar 2018.

[22] Lorenzo Pagliano, Paolo Zangheri, "Comfort models and cooling of buildings in the Mediterranean zone," Advances in Building Energy Research, vol. 4, no. 1, pp. 167-200, 2010.

[23] Gail Brager, David Lehrer, "Mixed-mode and case studies," Center for the Built Environment (CBE), University of California. Accessed 18 Mar 2018. http://www.cbe.berkeley.edu/mixedmode/index.html, Berkeley, 2013. 
[24] Elham Delzendeh, Song Wu, Angela Lee, Ying Zhou, "The impact of occupants' behaviours on building energy analysis: A research review," Renewable and Sustainable Energy Reviews, vol. 80, pp. 1061-1071, 2017.

[25] Sally S. Shahzad, John Brennan, Dimitris Theodossopoulos, Ben Hughes, John Kaiser Calautit, "Energy efficiency and user comfort in the workplace: Norwegian cellular vs. British open plan workplaces," Energy Procedia, pp. 807-812, August 2015.

[26] T. Yang, D. J. Clements-Croome, “in: Loftness V., Haase D. (eds). Natural Ventilation in Built Environment," in Sustainable Built Environments, New York, NY, Springer, 2013, pp. 394-425.

[27] Per Kvols Heiselber, "Design of Natural and Hybrid Ventilation," Department of Civil Engineering, Aalborg University, Aalborg, 2006.

[28] Madhavi Indraganti, Ryozo Ooka, Hom B. Rijal, Gail S. Brager, "Drivers and barriers to occupant adaptation in offices in India," Architectural Science Review, vol. 58, no. 1, pp. 77-86, 2014.

[29] Zhiqiang (John) Zhai, Mary-Hall Johnson, Moncef Krarti, “Assessment of natural and hybrid ventilation models in whole-building energy," Energy and Buildings, vol. 43, no. 9, pp. 2251$2261,2011$.

[30] Giacomo Chiesa, Mario Grosso, "Cooling potential of natural ventilation in representative climates of central and southern Europe," International Journal of Ventilation, vol. 16, no. 2, pp. 84-98, 2017.

[31] International Energy Agency (IEA), "Transition to Sustainable Buildings: Strategies and Opportunities to 2050," International Energy Agency (IEA), Paris, 2013.

[32] Miguel Mora-Pérez, Ignacio Guillen-Guillamón, Gonzalo López-Patiño, Petra Amparo LópezJiménez, "Natural Ventilation Building Design Approach in Mediterranean Regions. A Case Study at the Valencian Coastal Regional Scale (Spain)," Sustainability, vol. 8, no. 9, p. 855, 26 August 2016.

[33] Ivan Oropeza-Pereza, Poul Alberg Østergaard, "Potential of natural ventilation in temperate countries - A case study of Denmark," Applied Energy, vol. 114, pp. 520-530, 2014. 